\title{
COORDINATION BETWEEN PHYSICAL EDUCATION TEACHERS AND PHYSICAL THERAPISTS IN PHYSICAL EDUCATION CLASSES: THE CASE OF THE AUTONOMOUS COMMUNITY OF MADRID IN SPAIN
}

\author{
COORDENAÇÃO ENTRE PROFESSORES DE EDUCAÇÃO FÍSICA E \\ FISIOTERAPEUTA DURANTE AULAS DE EDUCAÇÃO FÍSICA: O CASO DA \\ COMUNIDADE AUTÔNOMA DE MADRID NA ESPANHA
}

\author{
COORDINACIÓN ENTRE PROFESORES DE EDUCACIÓN FISICA Y \\ FISIOTERAPEUTA DURANTE LAS CLASES DE EDUCACIÓN FISICA: EL CASO E \\ LA COMUNIDAD AUTÓNOMA DE MADRID EN ESPAÑA
}

\author{
Mario Díaz del Cueto*, Ariel Villagra Astudillo*, \\ Francisco Javier Castejón Oliva*
}

\section{Keywords:} Mainstreaming (Education).

Students.

Disabled persons. Physical Education.

Palavras chave: Inclusão educacional Estudantes. Pessoas com deficiência. Educação Física.

Palabras clave: Inclusión. Estudiantes.

Personas con discapacidad. Educación Física.
Abstract: The purpose of this study was to determine and analyse Physical Education (PE) teachers' perceptions about inclusion of students with physical disabilities in regular PE classes and how such inclusion could be improved by the contribution of other professionals. The information was obtained through a questionnaire administered to $56 \mathrm{PE}$ teachers and an interview with nine PE teachers and four physical therapists. The results reveal PE teachers' concern and uncertainty about providing quality attention to students with physical disabilities in their classes and their demand for specific training and support in class. They see the need for support from professionals such as Physical Therapists' when working with students with motor disabilities. We suggest further examination of the barriers faced by both professionals, their views on PE teachers and the physical therapists' role, as well as their willingness to collaborate with each other.

Resumo: O objetivo do estudo foi determinar e analisar as percepções dos professores que lecionam Educação Física (EF) a alunos com deficiência nas classes inclusivas de EF e como melhorar essa inclusão ao colaborar com o fisioterapeuta. A informação foi obtida através de um questionário administrado a 56 professores, que foi completado com entrevistas com nove deles e quatro fisioterapeutas. Os resultados mostram a preocupação e a incerteza dos professores sobre como servir os alunos com deficiência, a fim de oferecer uma educação de qualidade inclusiva e treinamento de demanda e suporte específico em suas aulas. Professores consideram necessário receber apoio de profissionais, como o fisioterapeuta, para que possam ajudar os alunos com deficiência motora. Sugerimos continuar a examinar as barreiras de ambos os profissionais, suas concepções de professores de EF e o papel do fisioterapeuta, bem como a sua vontade de colaborar entre si.

Resumen: El objetivo del estudio fue determinar y analizar las percepciones del profesorado de educación física que imparte clases al alumnado con discapacidad en las clases inclusivas de Educación Física y cómo mejorar esa inclusión cuando se colabora con el fisioterapeuta. Se obtuvo la información mediante un cuestionario administrado a 56 profesores, que se completó con entrevistas a nueve de ellos y a cuatro fisioterapeutas. Los resultados muestran la preocupación e incertidumbre del profesorado sobre cómo atender al alumnado con discapacidad para poder ofrecer una educación inclusiva de calidad y la demanda de capacitación y apoyos específicos en sus clases. El profesorado considera necesario el apoyo del fisioterapeuta como profesional adecuado para ayudar al alumnado con discapacidad motriz. Sugerimos seguir examinando las barreras de ambos profesionales, sus concepciones de EF y el papel del fisioterapeuta, así como su disposición a colaborar entre ellos.
*Universidad Autónoma de Madrid. Madrid, España.

E-mail: mario.diaz@uam.es; ariel.villagra@uam.es; javier.castejon@uam.es

Recebido em: 04-04-2018 Aprovado em: 13-03-2019 Publicado em: 11-04-2019

DOI: https://doi.org/10.22456/1982-8918.81733 (c) (1) \& Licence (a) 


\section{INTRODUCTION}

Four decades have gone by since the Warnock Report (1978) recommended students with disability attend and be integrated into the regular educational system. Following these recommendations, the Declarations of Salamanca (UNESCO, 1994) advanced towards educational inclusion. The European Disability Strategy 2010-2020, approved by the European Commission (EC, 2010) and international literature (HOWIE, 2010; ARMSTRONG; ARMSTRONG; SPANDOGOU, 2011), currently orient policies to improve educational levels internationally, and this should also include people with disabilities. The International Convention on the Rights of Persons with Disabilities adopted by the United Nations in December 2006 is in force and fully applicable in Spain since May 2008 and included in the currently Ley educativa (SPAIN, 2013).

Teachers should have a positive attitude to enhance students' active learning, improve performance and create less restrictive environments to allow full participation (BUTT, 2016). Many studies have concluded that teachers should receive adequate initial training, which would improve their attitudes towards students with disabilities (CAMBRIDGE-JOHNSON; HUNTER-JOHNSON; NEWTON, 2014). In this sense investigations (AZEVEDO; DE FREITAS, 2016; ROSE; O'NEILL, 2009) have stated that improvement in specific teacher training leads to full participation in this collaborative process of all persons in direct contact with the students. Research in Physical Education (PE) (MAHER; MACBETH, 2014) report that the professionals in charge of facilitating the inclusion of students with special educational needs are not properly trained to promote inclusion.-

In the last few decades, the World Health Organization (WHO, 2001), through the International Classification of Functioning, Disability and Health (ICF), have also recommended a collaborative process, starting with a global conception of the term Disability, to promote the joint and coordinated participation of the different professionals to achieve higher levels of inclusion. Therefore, the teachers and support staff should have a collaborative relationship in order to facilitate the inclusion of students with special educational needs. PE teachers require the help and cooperation from teaching or education assistants (GIANGRECO; DOYLE; SUTER, 2013). In PE, teachers need the incorporation professional assistants in their classes and cooperation with physical therapist (PT) in PE class is valued positively.

It is necessary to adequately design such collaboration because the incorporation of these assistants can lead to students with PD facing social isolation by limiting their interaction with other students (CERVANTES; LIEBERMAN; MAGNESIO; WOOD, 2013). Interactions in class would enhance the participation of students with and without a disability, thus enriching inclusion in normal classes leading to the sensitization of students without a disability, and without any negative effects on their learning (KLAVINA; BLOCK, 2008).

Therefore, considering our main theoretical proposal about staff in direct contact with students with PD, one of the teachers' demands to better meet the needs of students with a disability involves the help of another professional during the teaching-learning process (DAVIS et al., 2007). Support from specialised staff has a positive influence on the teachers' attitudes towards educational inclusion (FOURNIDOU; KUDLÁČEK; EVAGELLINOU, 2011).

However, professional instruction generally received by PTs during their initial and continued training provides them with a medical orientation, far removed from the educational 
approach received by the other professionals with whom they work in the schools (JASO; GÓMEZ-CONESA, 2005).

The Spanish Educational System (SPAIN, 2013) indicates how primary and secondary education with an inclusive orientation of the school curricula should be configured. The characteristic of these schools is that they be accessible to students with PD, in so far as the availability of school transportation and the elimination of architectural barriers, and the presence of a PT may be ensured.

In view of these needs, the purpose of this study was to determine and analyse PE teachers' perceptions of their role in the inclusion of students with PD in general PE class, as it relates to their training, and what measure to take to encourage a more inclusive environment with the collaboration of other professionals in direct contact with students with PD.

\section{METHOD}

Research methods, understood to be the procedures that describe, explain and predict phenomenon, in this case aims to examine how improvements in the way PE is taught could be attained when PE teachers are given assistance. To this end it is convenient to use different techniques to obtain data. We believe that it is better to offer several points of view and not a single point of view. That is, a combination of perspectives that clarify and not limit the study (SHANNON-BAKER, 2016). Therefore, the design of the research would be limited if only one perspective were used.

This reflection leads us to combine and reconcile quantitative research with qualitative research. Since each one separately would not offer sufficient evidence for the study's objectives, as is required for the quality in studies on disability (ALMALKI, 2016; ZITOMER, GOODWIN, 2014). The questionnaire was instrumental in collecting general, quantifiable data regarding the different realities and needs of PE teachers. The interviews identified what the said needs were concerning possible collaboration, which could be based on the characteristics of the teachers and the physiotherapists. This allowed for an in-depth analysis; it provided comprehension and solidity to the data to understand the PE teachers' reality, which was extracted from the combination of information extracted from the questionnaire and interviews. This leads us to the reflection that a sound combination of sources of information helps us to understand the reality faced by teachers whose instructional planning include accommodating students with disabilities.

In short, the research has been oriented towards mixed methods, which according to declarations made by Anguera, Camerino, Castañer y Sánchez (2014), both quantitative and qualitative methods understand research differently, both in the way of delimiting the problem and in the use of different sources of data.

\section{PARTICIPANTS AND CONTEXT}

We requested the participation of PE teachers from all the public schools of the Autonomous Community of Madrid (103 public schools: 62 Primary Schools and 41 Secondary Schools) that have students with PD. The invitation was made by regular mail and by phone. This procedure provided information about 56 PE teachers (29 men and 27 women; 54.4\%) 
from Primary Education ( $N=38,67.9 \%)$ and Secondary Education ( $N=18,32.1 \%)$ with different experience in teaching PE and groups that included students with PD (Table 1).

In our view, this number of participating teachers is sufficient as it is a statistical representation $(>50 \%)$ of the total sector under study of those that teach PE to students with motor disability.

Table 1 - Experience teachers $(\mathrm{N}=56)$

\begin{tabular}{lccccc}
\hline \multirow{2}{*}{ Teacher experience teaching PE } & \multicolumn{5}{c}{ Teacher experience with groups that included students with PD } \\
\cline { 2 - 6 } & $<5$ years & $\mathbf{5 - 1 0}$ years & $\mathbf{1 1 - 1 5}$ years & $>15$ & Total \\
\hline$<5$ & 8 & - & - & - & 8 \\
$5-10$ years & 11 & 8 & - & - & 19 \\
$11-15$ years & 1 & 3 & 2 & - & 6 \\
$>15$ & 1 & 5 & 5 & 12 & 23 \\
\hline Total & 21 & 16 & 7 & 12 & 56 \\
\hline \multicolumn{5}{c}{ Source: questionnaire }
\end{tabular}

Four PTs who work in the schools with these PE teachers also participated. Each PT has worked in several Primary and Secondary schools. Like other professionals, PTs are employed by the Educational Council of the Autonomous Community and they depend on the Board of Direction of the school where they work. Their functions are established in the Educational Standard (CIRCULAR, 2007, p. 2), and their "[...] main goal [...] is to help students [with PD] to maximize the development of their capacities, achieving the established educational aims [...]," as well as to institute the adequate adaptations.

We obtained permission from all the participants and assured them of the confidentiality of their data. In the case of the interviews, the researchers did not personally know the teachers in the study. The rationale for their selection can be found in some distinctive response made in the questionnaire, as will be seen in the following section. They were also informed that they could leave the study at any time if they did not want to continue participating. We followed the code of good practice in research as established by the authors' university (COMITÉ ÉTICA UAM, 2017).

\section{DATA COLLECTION}

The questionnaire administered was designed explicitly for this study. The initial version was devised drawing from the contributions of the bibliography and the knowledge of the researchers, as reflected in the study's aims. The questionnaire collected the opinions of Primary and Secondary PE teachers about aspects related to PE classes that include students with PD. It had 39 questions assessing personal data, knowledge about disability acquired in their initial and continuing professional development, level of coordination among the various professionals of the school, provision of specific material, infrastructure and complementary activities, etc. To validate the content and to select the most relevant and representative questions, this version was reviewed by two university researchers with acknowledged experience in the field of training and teaching PE, sport and support of students with PD, who have published articles on these issues in prestigious national and international journals, and have co-authored books on this subject during the past five years. Their suggestions were taken into account to produce the final version, with items rated either on a 4-point Likert-type response scale ranging from 1 (Always) to 4 (Never), or 
dichotomously (Yes/No). To determine the consistency of the instrument, we calculated Cronbach's alpha coefficient and achieved a reliability index of 0.78 for the entire questionnaire.

After analysing the information obtained through the questionnaire, we conducted semi-structured interviews with nine teachers (see Table 2), intentionally selected as a function of their responses to the questionnaire, and four PTs (see Table 3) in order to further our knowledge and clarify the teachers' responses about teaching groups of students with and without disabilities (PATTON, 2002). The questionnaire was not administered to the PTs. They were interviewed because the PE teachers had mentioned them in the questionnaire.

The reason for conducting the interviews was due to the fact that the researchers considered it necessary to provide a better understanding of the collaborative process between PE teachers and PTs. This collaboration is necessary (GIANGRECO; DOYLE; SUTER, 2013) when a real educational context with an orientation toward educational inclusion as indicated in the school curriculum (SPAIN, 2013) is being analysed, and which must also be viable with the perspective of the social model (OLIVER, 1992). As it will be seen later, the interviews have as function to contribute meaning and understanding, as well as contrast with the information obtained with the statistical analysis and a triangulation between the participating experts.

The basic questions of semi-structured interviews refer specifically to the possible participation of students with PD, as well as whether the collaboration and interaction with other professionals in direct contact with students with PD helped to improve these students' participation. All the interviews were conducted face to face, individually, and after requesting the interviewee's consent. The interviews took place at the professionals' schools.

\section{PROCEDURE}

We contacted the 56 PE teachers who agreed to participate by phone to explain the purpose of the study and arrange a meeting to apply the questionnaire. Some teachers were also asked to participate in the subsequent interviews. The questionnaire required about 45 minutes to complete. The investigators arrived at each of the secondary schools, distributed the questionnaires, and addressed any questions that arose, but without influencing the process. Once the questionnaires had been completed, the participants were invited to take part in an interview, during which protocol would be followed to ensure confidentiality. The questionnaires were then collected for their subsequent analysis.

Those teachers who had been selected for the interview were contacted by telephone. The teachers whose responses in the questionnaire had been chosen because they had the marked the highest in the degree of response on the rating scales (i.e., either Always or Almost always) in those categories dealing with coordination with PTs; the PTs were selected because they were singled out by the teachers in the questionnaire. Furthermore, one of the teachers has a double major: a degree in primary school teacher specialized in PE as well as a degree in PT, but works as a PT. The interviews were conducted by the investigators at the teachers' workplaces. Each interview lasted about 55 minutes. We requested the participants' permission to record the interview, ensuring them of the confidentiality of their data. They were given the transcript of the interviews and asked if they agreed with it. They did not add any relevant information to the interview. We interviewed the PTs a few weeks later, following the same procedure as with the PE teachers. 
Pseudonyms are used to identify the PE teachers and PTs. Tables 2 and 3 shows that the years of experience of the PE teachers and PTs. The interview with Roberto (PT) was conducted after the content analysis of the interviews with the other PTs.

Table 2 - Identification of the PE teachers who were interviewed in the study (Primary Education = PriEd; Secondary Education $=\mathrm{SecEd}$ ).

\begin{tabular}{lccc}
\hline Teacher & Educational Stage & $\begin{array}{c}\text { Number of years of } \\
\text { experience }\end{array}$ & $\begin{array}{c}\text { Number of years attending student } \\
\text { with PD }\end{array}$ \\
\hline María & PrEd & +15 & 15 \\
Andrés & $\operatorname{PrEd}$ & 15 & 5 \\
Julia & $\operatorname{PrEd}$ & 15 & 5 \\
Marta & SecEd & 15 & 15 \\
Manuela & SecEd & 15 & 15 \\
Sara & SecEd & 15 & 8 \\
Augusto & SecEd & +15 & 6 \\
Onofre & SecEd & 11 & 4 \\
Antonio & SecEd & 7 & 1 \\
\hline \multicolumn{5}{r}{}
\end{tabular}

Table 3 - Identification of the PTs of secondary education who were interviewed in the study

\begin{tabular}{lcc}
\hline PT & Number of years of experience & Number of years attending student with PD \\
\hline Javier & 15 & 15 \\
Cristina & 14 & 10 \\
Ana & 4 & 4 \\
Roberto & 13 & 8 \\
\hline
\end{tabular}

Source: date's research

\section{DATA ANALYSIS}

The response options for each questionnaire item were submitted to descriptive analysis (frequencies, percentages, valid percentage and accumulated percentage) with the SPSS program, version 17.0 (SPSS Inc., Chicago, Illinois, USA). This analysis allowed us to specify the two key issues of the study, based on the theoretical framework of this document: (a) education and training services, systems and policies among the environmental factors that facilitate inclusion; and (b) the collaborative relationships between professionals who work directly with students with PD. The transcript contents of the interviews were then manually and individually analysed inductively, relating the questionnaire dimensions to the study goals and comparing the cases by cross-case analysis (LECOMPTE; SCHENSUL, 1999). This process identified the theoretical categories, in order to classify the most relevant issues emerging during the initial readings.

To validate the report, we contrasted the information obtained with each instrument from each teacher and PT. This triangulation was also performed by the researchers, based on the contributions of the consulted literature and the researchers' own experience and knowledge. All the discourses present in each one of the instruments were globally analysed to achieve a comprehensive approach to the process as a whole. The teachers were asked to verify the researchers' data analysis. 
In this work, we will use the following two categories corresponding to the purpose of the study, and defined according to the questionnaire input and documented through the interviews:

(a) PE teachers' perception of the participation of students with PD in class.

(b) Support and collaboration of the PT in the teaching-learning process.

\section{RESULTS AND DISCUSSION}

\section{1 PE TEACHERS' PERCEPTION OF THE PARTICIPATION OF STUDENTS WITH PD IN CLASS}

The continued attendance of students with PD in PE class does not seem to follow a clear pattern in the cases analysed. Table 4 shows (question \#28) that $37.5 \%$ of the surveyed teachers responded Always to the item asking whether students with PD go to class regularly (the response options Always and Almost always make up 76,\%), although we think this percentage should be higher, regarding the total PE class schedule.

Table 4 - Percentage of responses to questions about PE class attendance of students with PD. $(N=56)$

P. 28. Do students with a physical disability regularly attend (or did they attend if you do not teach groups that include students with disabilities this academic year) physical education classes?

\begin{tabular}{lcccc}
\hline & Frequency & Percentage & Valid percentage & Accumulated percentage \\
\hline Always & 21 & 37.5 & 37.5 & 37.5 \\
Almost always & 22 & 39.2 & 39.2 & 76.8 \\
Sometimes & 12 & 21.4 & 21.4 & 98.2 \\
Never & 1 & 1.8 & 1.8 & 100.0 \\
\hline Total & 56 & 100.0 & 100.0 &
\end{tabular}

No clear pattern of percentages was observed when asking (Table 5) in question \#29 about these students' going to the PT during PE class hours.

Table 5 - Percentage of responses to questions about students with a physical disability see the physiotherapist during physical education class time $(N=56)$

\begin{tabular}{lcccc}
\hline P. 29. Do or did students with a physical disability see the physiotherapist during physical education class time? \\
\hline & Frequency & Percentage & Valid percentage & Accumulated percentage \\
\hline Always & 8 & 14.2 & 14.2 & 14.2 \\
Almost always & 13 & 23.2 & 23.2 & 37.4 \\
Sometimes & 29 & 51.7 & 51.7 & 89.1 \\
Never & 6 & 10.7 & 10.7 & 100.0 \\
\hline Total & 56 & 100.0 & 100.0 & \\
\hline \multicolumn{5}{c}{ Source: questionnaire }
\end{tabular}

Although a greater (Table 6) percentage of teachers indicated in question \#38 that these students attended complementary and extra-curricular PE activities. 
Table 6 - Percentage of responses to questions about students with a physical disability that participate in complementary activities or extracurricular activities. $(N=56)$

P. 38. Do students with a physical disability participate in complementary activities or extracurricular activities that the Department of Physical Education organize?

\begin{tabular}{lcccc}
\hline & Frequency & Percentage & Valid percentage & Accumulated percentage \\
\hline Always & 15 & 26.3 & 26.8 & 26.8 \\
Almost always & 23 & 40.4 & 41.1 & 67.9 \\
Sometimes & 17 & 29.8 & 30.4 & 98.2 \\
Never & 1 & 1.8 & 1.8 & 100.0 \\
\hline Total & 56 & 100.0 & 100.0 & \\
\hline \multicolumn{5}{c}{ Source: questionnaire }
\end{tabular}

Apparently, attending PE class is not continuous because it is usually alternated with visits to the PT, depending on the characteristics and level of each disability. We tried to clarify this point with information from the interviews.

According to the data from the questionnaire, the PE teachers and PTs are usually present while PE classes are in session, assisting students with PD. That is, they share their professional functions, but it is not clear whether they also jointly perform their duties with both students with PD and other class members. The information provided by the PE teachers and PTs during the interview was used to clarify any doubts.

Regarding the decisions of the school principal concerning the class schedule for students with PD, the teachers think that PE class attendance of students with PD depends on various factors. Thus, one criterion when assigning the PT's schedule to attend to students with PD seems to be the curricular weight of the subjects. That is, visits to the PT do not coincide with curriculum subjects that are considered 'more relevant or more important', as can be seen by the comment of Andrés: "The schedule for the PT to see to students with PD generally coincides with PE. It does not coincide with Language or Mathematics."

This Primary Education pattern is also found in Secondary Education. According to Antonio, students with PD attend PE class one day but the next day, they go to the PT.

However, on the day they go to PE class, they do not participate with the other students because they work separately with an instructor who helps them with specific exercises: Antonio: "I spend two days with her (student with PD), one day she goes to the PT and the next day, following the guidelines of the PT, a coach comes and helps her work with a walker."

This rate of attendance between the PE class and the session with the PT is also the case of María. However, she equates PE or PT attendance to the degree of disability: "In general, they all come for one hour, one session, and the other hour corresponds to the PT. Some come to two classes, but that depends on the degree of the child's disability."

Apparently, unless there is a rule specifying how often students with PD should visit the PT coinciding with PE classes, the most widespread pattern is for both professionals to "share" students with PD. Collaboration among these professionals varies considerably, but the principle of inclusiveness should prevail so that all the students can achieve the goals of their educational stage (HAYCOCK; SMITH, 2011; RAIMUNDO, 2014). The following limitations to attend to students with disabilities have been established: the teaching staff's knowledge, 
class heterogeneity, the degree of disability, and the lack of support from assistants (BLOCK; OBRUSNÍKOVÁ, 2007; ROSE; O'NEILL, 2009); the PE teacher should lead the process of collaboration to enhance inclusion.

Some of the problems about students with PD attendance to PE classes with an inclusive orientation may be related to teachers' perceptions of the difficulty and their uncertainty concerning these students. Such perceptions are consistent with the information the PE teachers in this study contributed in the questionnaire (question \#17: To what extent do you consider it necessary to improve your training in dealing with students with a disability?) when $94.8 \%$ answered it was Extremely necessary and Very necessary to improve their training, a need also seen at an international level as reported in other studies (e.g., VICKERMAN; COATES, 2009). Likewise, Antonio, who also thinks they may be due to the insufficient training received, states: "[...] yes, I worry about what I am going to do with her [student with PD]. I really think that we don't get enough training. Right now, I don't know what to do with her."

The last comment confirms that teacher training is insufficient to achieve the educational goals demanded of them (HAYCOCK; SMITH, 2011). Quality assistance and participation of students with PD in PE classes requires a conjunction of factors, as noted by O'Brien, Kudláček and Howe (2009, p. 58): 'The success of inclusion is greatly increased when various factors such as support, personnel, training and positive attitudes exist.' In this sense, for Augusto, it is important for students with PD to attend his classes because it could help them to improve their social skills:

Augusto: In our Department, it is clear to us that the more time they (students with PD) spend with students without disabilities, the better. But I have a class in which there are two students with PD, and I sometimes feel that they are not part of the class.

Another important factor to achieve inclusion is that most of the activities of the PE classes be carried out conjointly, i.e., having students with and without disabilities in the same class (BLOCK; KLAVINA; FLINT, 2007; KLAVINA; BLOCK, 2008). Onofre sees participation important, but in this case, students' different possibilities of task engagement may eventually bore them, thereby reducing activities of higher motor competence:

Onofre: Sometimes I see that some students are bored; maybe not all of them, but a large number. They think that this person (student with PD) does not let them work [...] that because of this person, they cannot perform certain activities.

We deem that if PE classes are to provide not only motor improvements, but also psychological and social quality to achieve inclusion, these students should attend the same number of classes as their classmates (e.g. HAYCOCK; SMITH, 2011).

\subsection{SUPPORT AND COLLABORATION OF THE PT IN THE TEACHING-LEARNING PROCESS}

The results of the questionnaire (Table 7) show that the PE teachers of the study, in question \#31, reveal that the direct support of another professional would favour the participation of students with PD in their classes. 
Table 7 - Percentage of responses concerning the collaboration of the direct support professional in the teaching-learning process $(N=56)$

31. Do you believe that the presence of direct support professional in physical education classes could encourage participation among students with a physical disability?

\begin{tabular}{lcccc}
\hline & Frequency & Percentage & Valid percentage & Accumulated percentage \\
\hline Always & 29 & 50.9 & 51.8 & 51.8 \\
Almost always & 15 & 26.3 & 26.8 & 78.6 \\
Sometimes & 11 & 19.3 & 19.6 & 98.2 \\
Never & 1 & 1.8 & 1.8 & 100.0 \\
\hline Total & 56 & 100.0 & 100.0 & \\
\hline \multicolumn{5}{c}{ Source: questionnaire }
\end{tabular}

However (Table 8), in question \#33, 78.5\% of the teachers who participated in the study responded that a support professional is only Sometimes or Never present.

Table 8 - Percentage of responses concerning the collaboration of the direct support professional in the teachinglearning process $(N=56)$

33. Is or Was professional support present in your physical education classes in which students with a physical disability attend(ed)?

\begin{tabular}{lcccc}
\hline & Frequency & Percentage & Valid percentage & Accumulated percentage \\
\hline Always & 4 & 7.1 & 7.1 & 7.1 \\
Almost always & 8 & 14.2 & 14.2 & 21.3 \\
Sometimes & 16 & 28.5 & 28.5 & 49.5 \\
Never & 28 & 50.0 & 50.0 & 100.0 \\
\hline Total & 56 & 100.0 & 100.0 & \\
\hline \multicolumn{5}{c}{ Source: questionnaire }
\end{tabular}

Coinciding with ROSE; O'NEILL, (2009) with regards to the possibility of having a direct support professional in class, Manuela states that without the necessary support, the participation of the student with PD could lead to decreasing attention to the rest of the students: "[...] what you cannot do is let that girl [with PD] warm up by herself, nor can you attend to her and leave the rest of the group. The best thing would be for there to be a support person to accompany her."

In this respect, the PE teachers in this study, when (Table 9) they answer Question \#32 regarding the profile of the direct support professional. The majority, exactly $64.3 \%$, state that the PT is a support professional who attends their classes.

Table 9 - Percentage of responses concerning the profile of the direct support professional $(N=56)$

\begin{tabular}{lcccc}
\hline \multicolumn{5}{c}{ 32. What sort of profile do you think the professional assistance should have? } \\
\hline & Frequency & Percentage & Valid percentage & Accumulated percentage \\
\hline Physical Therapists & 36 & 64.3 & 64.3 & 64.3 \\
Other PE Teachers & 12 & 21.5 & 21.5 & 85.8 \\
Pedagogical advisor & 4 & 7.1 & 7.1 & 92.9 \\
Others technical assistants & 4 & 7.1 & 7.1 & 100.0 \\
\hline Total & 56 & 100.0 & 100.0 & \\
\hline \multicolumn{5}{l}{ Source: questionnaire } \\
\end{tabular}


We have noticed that in the comment made by Augusto (PE) that having a PT as a collaborator in the teaching-learning process, supports him by providing relevant information about students with PD: "I usually have a meeting with the PT at beginning of the course, and he tells me exactly what type of pathology the student has and what he can do, and he helps me to adapt the curriculum. I could not teach the class without his help."

In the information provided by the questionnaire, we observed that the participant teachers considered the support of others necessary to respond appropriately to students with $\mathrm{PD}$ in their classes, and that this collaborative process improves students' performance (RAIMUNDO, 2014). However, when the PE teachers could clearly see that they could adapt the content, or the material, or when the student's disability was mild, they found other collaborative possibilities that they also considered enriching. There was the example of the researcher asking Marta if the students without PD, through their collaboration, could replace the support provided by assistant teacher or PT.

Marta: In concrete things, yes. If you tell them to play badminton with smaller rackets, then the student with PD can play; or to throw a ball with or without dribbling...Yes, because these are targeted tasks. I wouldn't dare do more than this.

This possibility expressed by Marta about the collaboration of students without PD (KLAVINA; BLOCK, 2008), and her opinion that the participation of students with PD need not affect the learning of the students without PD coincides with that of OBRUSNÍKOVÁ et al. (2003). In contrast, María does not think this is feasible or she does not put it into practise, either because of a more severe level of disability, or because of her perception of PE as being eminently practical, or her lack of knowledge: "What can you do with 28 students if all the support is taken away and you're all alone? The first thing I feel, even now, after more than 15 years, is anxiety, a lot of anxiety."

We think the teachers' doubts, also due to the need for more specific knowledge, could be resolved by the presence of a support professional. Collaboration does not seem hard to achieve according to the study of Reeder et al. (2011), which concludes that PTs' collaboration is valued because of the intervention strategies they provide and the collaborative use of these strategies. Simon, Fügedi and Bognár (2010) think that such collaboration is feasible; they state that among others, the main differences between the functions of the PE teacher and the school PT are the attention to and treatment of students with PD depending on their degree of disability and muscle development.

Teachers' and PTs' conceptions of the purpose of motility (which are not only motor) and of how to work on motility in the educational setting should converge so that PTs' collaboration would be enriching for students with PD. As noted by Jaso and Gómez-Conesa (2005, p. 151), "The development of physical therapy in schools has its own identity and different characteristics from jobs in public health, private practice, or nursing homes." PT Ana thinks that this educational concept of physical therapy allows teachers and PTs to work together at times, although the PTs' viewpoint is essentially medical:

Ana: In part, we are working on the same issues, it is complementary. Some children have problems with their fingers and toes. When assessing these children, we should not only work on the hand, but also the elbow, shoulder, and neck. What I work on is complementary to what the PE teacher does. 
Again, for the teachers, the educational setting is a priority, and there must be some coordination with the leadership of the PE teacher, so that the educational goals are not forgotten. Nevertheless, Cristina considers the possibility of coordinating without attending the PE class, informing the PE teacher which exercises the student with PD should perform, although she is aware that this situation prevents the interaction of students with and without PD. Her view is based on a traditional medical model (LEVANGIE, 1980) of physical therapy at school, together in class, but separated in activities:

Cristina: We are coordinated. I have created a table of exercises that takes into account some of the students' characteristics. The teachers use the table and the student does the stretches (from the table of exercises) she needs to do while the others play basketball.

Although this view of physical therapy at school is not shared by all the professionals, we see from the statement of PT Javier that, depending on the degree of the PD, another type of coordination and support can be employed: "If it is a lack of motor coordination, the student can perform a PE class perfectly well. We can work on activities of coordination, balance [...] with the support of the PT in the PE class."

PT Roberto considers that it is essential for these professionals to meet and coordinate to design the teaching units and sessions, and to reach agreements about their goals (i.e., the learning aims): "I think that the first thing would be a meeting prior to each didactic unit to determine the goals. They should reach some agreement about the goals of some of the sessions."

Roberto and Javier's view of the role of the PT coincides with the regulations of the Administration (CIRCULAR, 2007) concerning the fulfilment of educational goals. Roberto analyses some of the professionals' differences concerning the functions and goals of PE and physical therapy at school, based on his knowledge both as a PT and a PE teacher.

He believes the current differences between the two professionals are, among other things, related to their concepts of the role of their disciplines:

Roberto: There is a lot of confusion and lack of knowledge. Some teachers associate physical therapy with massage and resting. At school, this perception is wrong because we use other techniques. PTs still have the idea that all the students do in PE class is run, practise free sport and enjoy themselves. They forget that students work on many things that no other area provides.

Roberto thinks that the beliefs about what these disciplines can provide students with PD do not correspond to what they currently offer, so it is necessary to familiarize the other members of the educational community with the functions and benefits of the two disciplines. In accordance with Jaso and Gómez-Conesa (2005), Roberto considers that initial training in teamwork for PE teachers and PTs should be reinforced to overcome the weaknesses of both disciplines.

\section{CONCLUSIONS}

For the teachers who participated in this study, the inclusion in PE classes of students with and without disabilities is necessary because of the social skills they learn. Nevertheless, the teachers acknowledge their insecurity when attending to students with PD in their classes, 
because they perceive that they are not sufficiently well trained to achieve the educational goals, especially those of inclusion. Hence, they request collaboration from other professionals. Another PE teacher or even a student without any diagnosed disability can take on the role of support person during class.

In this sense, we consider it very significant that, based on the information provided by the questionnaire, PE teachers consider the presence of a support professional to be very necessary during physical education classes as it can encourage participation of students with PD, and prefer this support be provided by PTs. According to our study, it may be because he/ she is the most qualified professional that can best understand and help provide quality PE instruction to students with disabilities and ensure their inclusion. This need contrasts with the low rate of attendance of a support professional to the classes, which has been argued by PE teachers to significantly enrich the lessons, making PTs highly sought after.

In fact, a PT can also be this support person because of their knowledge of the characteristics of disability, and the fact that the PT's role is related to the student's motor skills. Most of the PTs who collaborated in the study agree with these views, with some nuances about how to collaborate and offer support in PE classes, particularly because of their lack of pedagogical training.

Collaboration between the PE teachers and the PTs of our study depends largely on their relationship, i.e. their personal and professional good will. These professionals' perceptions of the functions of PE and physical therapy at school will have an impact on the quality and quantity of participation of students with PD and on the relations and interactions between students with and without disabilities in PE classes. As shown in the responses during the interview, PE teachers need support to achieve quality in inclusive education. Both PE teacher and PT staff need to identify their limitations and combine their expertise to make informed decisions.

Despite the limitations of the study and the scarce literature on this subject (at least to our knowledge), this study's contributions are relevant. More so, the idea that collaboration between PE teachers and PTs should start with the process of designing the tasks and prior activities included in the syllabus, which has been based on the PT's diagnosis. This collaboration should extend to the classroom, to interaction in activities and, if possible, in the assessment of the outcomes. Determining barriers to such collaboration, with negative consequences for the adequate participation of students with PD in inclusive settings, is also relevant. It should be taken into account that, according to the regulations in force, both professionals have the same goal and are members of the team that should attend to students with PD in 'preferentially motor' schools.

We think that this study clears the way for future research. The determination of the barriers of both professionals, their conceptions of PE and physical therapy in terms of implementing motility in educational settings, as well as their roles in schools are some of the needs that should be examined in future research and dealt with by improving the training of both professionals.

Likewise, we consider that even though the present article provides an original and unpublished instrument expressly designed for this study i.e., an ad hoc questionnaire, a possible line of investigation, for future reference, could be to analyze its measure quality, estimating its temporal reliability through test-retest. 


\section{REFERENCES}

ALMALKI, Sami. Integrating Quantitative and Qualitative Data in Mixed Methods ResearchChallenges and Benefits. Journal of Education and Learning, v. 5, n. 3, p. 288-296, 2016.

ANGUERA, Maria Teresa; CAMERINO, Oleguer; CASTAÑER, Marta; SÁNCHEZ-ALGARRA, Pedro. Mixed methods en la investigación de la actividad física y el deporte. Revista de Psicología del Deporte, v. 23, n. 1, p. 123-130, 2014.

ARMSTRONG, Derrick; ARMSTRONG, Ann Cheryl; SPANDAGOU, llectra. Inclusion: by choice or by chance? International Journal of Inclusive Education, v. 15, n. 1, p. 29-39, 2011.

AZEVEDO, José Milton; DE FREITAS, Ana Paula. Possibilidades de atuação do professor de educação física no processo de aprendizagem de alunos com deficiência. Movimento, v. 22, n. 4, p. 1163-1176, out./dez. 2016.

BLOCK, Martin; KLAVINA, Aija; FLINT, Wayne. Including students with severe, multiple disabilities in general physical education. Journal of Physical Education, Recreation, and Dance, v. 78, n. 3, p. 29-32, 2007.

BLOCK, Martin; OBRUSNÍKOVÁ, Iva. Inclusion of physical education: A review of the literature from 1995-2005. Adapted Physical Activity Quarterly, v. 24, n. 2, p. 103-124, 2007.

BUTT, Rosemary. Teacher assistant support and deployment in mainstream schools. International Journal of Inclusive Education, v. 20, n. 9, p. 995-1007, 2016.

CAMBRIDGE-JOHNSON, Janelle; HUNTER-JOHNSON, Yvonne; NEWTON, Norissa. Breaking the Silence of Mainstream Teachers' Attitude towards Inclusive Education in the Bahamas: High School Teachers' Perceptions. The Qualitative Report, v. 19, n. 42, p. 1-20, 2014

CERVANTES, Carlos; LIEBERMAN, Lauren; MAGNESIO, Betsy; WOOD, Julie. Peer Tutoring: Meeting the demands of inclusion in physical education today. Journal of Physical Education, Recreation \& Dance, v. 84, n. 3, p. 43-48, 2013.

CIRCULAR. Dirección General de Centros Docentes relativa a las actuaciones de los fisioterapeutas en el ámbito escolar. Madrid: Comunidad de Madrid, 2007. Disponível em: http://www.madrid.org/. Acesso em: 16 out. 2015.

COMITÉ ÉTICA UAM. Research Ethics Committee. Madrid: University, 2017. Disponível em: https://www.uam.es/UAM/ComEt-Documentos/1446745195850.htm?language=Comit?\%20de\%20 ?tica\%20de\%20la\%20Investigaci?n. Acesso em: 2 dez. 2014.

COMUNIDAD DE MADRID. Informe 2013 sobre el sistema educativo en la Comunidad de Madrid. Madrid: Consejo Escolar de la Comunidad de Madrid, 2013. Disponível em: http://www. madrid.org/bvirtual/BVCM016177.pdf. Acesso em: 10 out. 2015.

DAVIS, Ronald; KOTECKI, Jerome; HARVEY, Michael; OLIVER, Amy. Responsibilities and training needs of paraeducators in physical education. Adapted Physical Activity Quarterly, v. 24, n. 1, p. 70-83, 2007.

EUROPEAN COMMISSION. Communication from the Commission to the European Parliament, the Council, the European Economic and Social Committee and the Committee of the Regions European Disability Strategy 2010-2020: A Renewed 
Commitment to a Barrier-Free, 2010. Disponível em: http://eur-lex.europa.eu/legal-content/ES/ ALL/?uri=CELEX:52010DC0636. Acesso em: 2 dez. 2014.

FOURNIDOU, Ioanna; KUDLÁČEK, Martin; EVAGELLINOU, Christina. Attitudes of in-service physical educators toward teaching children with physical disabilities in general physical education classes in Cyprus. European Journal of Adapted Physical Activity, v. 4, n. 1, p. 22-38, 2011.

GIANGRECO, Michael; BROER, Stephen; SUTER, Jesse. Guidelines for Selecting Alternative to Overreliance on Paraprofessionals: Field-Testing in Inclusion-Oriented Schools. Remedial and Special Education, v. 32, n. 1, p. 22-38, 2011.

HAYCOCK, David; SMITH, Andy. To assist or not to assist? A study of teachers' views of the roles of learning support assistants in the provision of inclusive physical education in England. International Journal of Inclusive Education, v. 15, n. 8, p. 835-849, 2011.

HOWIE, Dorothy. A comparative study of the positioning of children with special educational needs in the legislation of Britain, New Zealand and the Republic of Ireland. International Journal of Inclusive Education, v. 14, n. 8, p. 755-776, 2010.

JASO, Marta; GÓMEZ-CONESA, Antonia. Desarrollo de la fisioterapia en centros de educación primaria y secundaria. Physioterapia, v. 27, n. 3, p. 146-151, 2005.

KLAVINA, Aija; BLOCK, Martin. Peer tutoring in inclusive PE. Adapted Physical Activity Quarterly, n. 25, p. 132-158, 2008.

LECOMPTE. Margaret; SCHENSUL, Jean. Analyzing and interpreting ethnographic data. Walnut Creek, CA: Alta Mira, 1999.

LEVANGIE, Pamela. Public school physical therapists: Role definition and educational needs. Physical Therapy, v. 60, n. 6, p. 774-779, 1980.

MAHER, Anthony; MACBETH, Jessica. Physical education, resources and training: The perspective of special educational needs coordinators working in secondary schools in North-West England. European Physical Education Review, v. 20, n. 1, p. 90-103, 2014.

NUNNALLY, Jum. Psychometric theory. New York: McGraw-Hill, 1978.

O’BRIEN, Deirdre; KUDLÁČEK, Martin; HOWE, Peter David. A contemporary review of English language literature on inclusion of students with disabilities in physical education: A European perspective. European Journal of Adapted Physical Activity, v. 2, n. 1, p. 46-61, 2009.

OLIVER, Mike. Changing the Social Relations of Research Production? Disability, Handicap \& Society, v. 7, n 2, p. 101-114, 1992.

PATTON, Michael Quinn. Qualitative research and evaluation methods. 3. ed. Thousand Oaks, CA: Sage, 2002.

RAIMUNDO, Celina Luísa. Inclusive Physical Education: Teachers' Attitudes. Movimento, v. 20, n. 2, p. 637-657, abr.jun. 2014.

REEDER Deborah L.; ARNOLD Sandra; JEFFRIES Lynn; MCEWEN, Irene. The role of occupational therapists and physical therapists in elementary school system early intervening services and response to intervention: A case report. Physical \& Occupational Therapy in Pediatrics, v. 31, n. 1, p. 44-57, 2011. 
ROSE, Richard; O'NEILL, Áine. Classroom support for inclusion in England and Ireland: An evaluation of contrasting models. Research in Comparative and International Education, v. 4, n. 3, p. 250-261, 2009.

SHANNON-BAKER, P. Making Paradigms Meaningful in Mixed Methods Research. Journal of Mixed Methods Research, v. 10, n. 14, p. 319-334, 2016. https://doi. org/10.1177/1558689815575861

SIMON, István; FÜGEDI, Balázs; BOGNÁR, József. Adapted physical education in the Hungarian educational system: A conceptual framework. Journal of Human Sport \& Exercise, v. 5, n. 3, p. 453-461, 2010.

SPAIN. Ley Orgánica 8/2013, de 9 de diciembre, para la mejora de la calidad educativa. 2013. Disponível em: http://www.boe.es/boe/dias/2013/12/10/pdfs/BOE-A-2013-12886.pdf Acesso em: 17 jan. 2014.

UNESCO. The Salamanca Statement and Framework for Action on Special Needs Education. Madrid: UNESCO and Ministry of Education and Science (Spain), 1994.

VICKERMAN, Philip; COATES, Janine Kim. Trainee and recently qualified physical education teachers' perspectives on including children with special educational needs. Physical Education \& Sport Pedagogy, v. 14, n. 2, p. 137-153, 2009.

WARNOCK, Mary. Special educational needs. Report of the committee of enquiry into the education of handicapped children and young people. London: HMSO, 1978.

WORLD HEALTH ORGANIZATION. International classification of functioning, disability and health (ICF). Geneva, 2001.

ZITOMER, Michelle R., GOODWIN, Donna. Gauging the quality of qualitative research in adapted physical activity. Adapted Physical Activity Quarterly, v. 31, n. 3, p. 193-218, 2014. https://doi.org/10.1123/apaq.2013-0084 